\title{
Makna Rahasia Wahyu Pertama (Kajian Stilistika Al-Qur'an)
}

Muhammad Alghiffary

Pendidikan Bahasa Arab

IAIN Pekalongan muhammad.alghiffary@iainpekalongan.ac.id

Abstract: In the midst of the repressive and compelling methods of Islamic $d a$ 'wah, the first revelation was presented to remind the Prophet's da'wah method in the midst of the Quraysh community. The first revelation was made a material object, because it has a style of language associated with the method of propagation of the Prophet. In addition, the first revelation also opened the model of the Prophet's preaching. Stylistics as a formal object is able to parse language style to find a picture of the situation and context of the problem at that time. The domain of this article is morphological (almustawà al-awarfi). The morphological domain was chosen because it could represent the discussion of other domains. Through the descriptive method the research results are obtained that the Prophet's method of persuasion is obtained through the description of the disposal of objects in the word iqra 'as fi muta'addi. In this context the Messenger of Allah did not immediately order the Quraysh to read the scriptures they brought. The first revelation also provides conditions for preachers. One of the requirements needed by a preacher is the nature of the pious. This trait is obtained through a long effort and process. In addition, a preacher also must always repeat knowledge in order to gain firm conviction. In introducing God, Rasulullah used persuasive, latent, and careful methods. The word Rabbun is an antithesis of belief that is packaged in a singular form to awaken the Quraysh people about the nature of the One God.

Keywords: Meanings, Stylistic, The first reveal. 


\section{Pendahuluan}

Fenomena kekerasan beragama marak terjadi. Salah satu kemungkinan penyebabnya ialah pemaksaan teks terhadap kehidupan masyarakat. Segala tindakan represif dibenarkan untuk mematuhi bunyi teks tanpa ada pertimbangan budaya. Para da'i tidak segan menghancurkan dan membinasakan sesuatu yang bertentangan dengan ajaran. Tindakan ini berlawanan dengan metode Rasulullah dalam mengajarkan ajaran agama. Wahyu pertama menyimpan gambaran dakwah Rasulullah yang masih tersembunyi di balik gaya bahasanya. Diksi-diksi yang dipakai mengandung makna-makna yang berhubungan dengan metode dakwah Rasulullah.

Makna, secara etimologi, berarti maksud penulis atau pembicara (Pusat Bahasa Depdiknas, 1988). Adapun secara terminologis, Kridalaksana mendefinisikan makna dengan satuan bahasa yang dapat mempengaruhi pemahaman pembaca atau pendengar (Kridalaksana, 2009). Makna, menurut Jāhị adalah sesuatu yang tertutupi, letaknya jauh dan terhalang. Makna hanya dapat diambil melalui sesuatu selain makna itu sendiri yang disebutnya dengan bayān (penjelasan) (Al-Jahiz,1948). Berdasarkan penjelasan dua tokoh tersebut, terdapat dua cara untuk mendapatkan makna, yaitu: pemahaman dan penjelasan. Pemahaman digunakan untuk mendekati makna, sedangkan penjelasan digunakan untuk mempublikasikan makna.

Stilistika digunakan sebagai alat untuk memahami keberadaan makna, karena mampu merobek struktur bahasa secara radikal sehingga didapatkan makna tersembunyi. Menurut Nyoman, stilistika adalah ilmu yang mempelajari tentang gaya. Menurutnya, gaya adalah cara tertentu untuk mengungkapkan sesuatu, sehingga tujuan dapat diperoleh secara maksimal (Ratna, 2009). Meminjam bahasa Saussure, gaya merupakan sebuah parole yang bersifat pribadi. Seseorang yang sedang berkomunikasi memiliki ciri khas yang tidak dimiliki oleh orang lain. Oleh karena itu, fokus pada ciri khas tersebut merupakan cara terbaik untuk mendapatkan maksud komunikator. 
Wahyu pertama dijadikan sebagai objek material, karena menjadi landasan dan pembuka wahyu-wahyu setelahnya. Wahyu pertama merupakan kunci pengetahuan dalam memahami wahyuwahyu setelahnya. Dengan memahami gaya bahasa wahyu pertama, posibilitas gambaran awal tentang gaya bahasa wahyu-wahyu setelahnya bisa didapatkan.

\section{Metode Penelitian}

Penelitian ini menggunakan metode deskriptif analitik, karena bersifat penggambaran. Nyoman membagi metode menjadi tiga, metode pengumpulan data, metode analisis data, dan metode penyajian analisis data. Penggunaan ketiga metode ini mempermudah jalannya proses penelitian (Ratna, 2010).

Dalam mengumpulkan data, penelitian ini menggunakan metode perpustakaan, karena berhubungan dengan literatur-literatur kepustakaan. Literatur-literatur tentang wahyu pertama dikumpulkan untuk dianalisis. Proses analisisnya menggunakan metode deskriptif analitik, karena menggambarkan penjelasan-penjelasan tanpa disertai statistik, diagram, dan angka-angka. Kata-kata dalam wahyu pertama dijelaskan secara mendalam dengan cara pendefinisian dan perbandingan. Hasilnya disajikan menggunakan narasi.

\section{Hasil dan Pembahasan}

\section{a. Argumentasi Pemilihan Stilistika}

Stilistika diambil dari kata style atau stylus (bahasa latin) yang berarti bulu burung. Selain bulu burung, ada pula pendapat lain yang mengatakan bahwa stylus berarti besi berujung bulat seperti titik yang biasa digunakan oleh orang-orang terdahulu sebagai alat untuk menulis di atas papan yang dilapisi lilin (Qalyubi, 2008). Ada pula pendapat yang mengatakan alat untuk menulis di atas tanah liat keras yang belum kering pada tahun 3000 SM (Finkel, 2014).

Secara umum style, sebagaimana dijelaskan Nyoman, berarti caracara yang khas untuk mengungkapkan segala sesuatu, sehingga tujuan yang dimaksud dapat dicapai secara maksimal (Ratna, 2009). Pendapat senada juga diungkapkan Khitam yang mengatakan bahwa style berhubungan dengan cara, konteks, dan tujuan tertentu (Khitam, 
2017). Meskipun style yang dimaksud Nyoman masih bersifat umum, namun jika diperhatikan definisi tersebut hendak memberitahukan bahwa cara khas yang dimaksud adalah bahasa verbal. Hal ini dapat dilihat melalui tiga kata kunci yang ada, yaitu: khas, tujuan, dan maksimal. Banyak para tokoh linguistik yang menyatakan bahwa bahasa verbal merupakan alat yang paling sempurna untuk menyampaikan tujuan.

Pernyataan tersebut diperkuat oleh penjelasan Harimurti yang mengatakan bahwa stilistika adalah ilmu yang menyelidiki bahasa yang digunakan dalam karya sastra atau penerapan linguistik pada penelitian gaya bahasa(Kridalaksana, 2009). Penjelasan Harimurti ini mulai mengerucut pada objek kajian stilistika, yaitu karya sastra. Secara historis, bisa dikatakan bahwa Harimurti menganut madzhab platonik, karena menganggap bahwa gaya tidak terdapat dalam semua ekspresi.

Berbeda dari Harimurti, dalam pembahasan ini penulis mengikuti madzhab Aristotelian yang menganggap bahwa gaya merupakan sebuah kualitas inhern dalam semua bentuk ekspresi. Yang membedakan adalah superioritas dan inferioritas gaya, kuat lemahnya gaya, dan baik tidaknya gaya (Ratna, 2009). Dengan demikian objek kajian stilistika menurut madzhab Aristotelian lebih luas dibanding madzhab Platonik, sehingga dapat diterapkan pada semua karya.

Apabila dihubungkan dengan al-Qur'an, stilistika dapat didefinisikan dengan ilmu yang menyelidiki bahasa yang digunakan dalam al-Qur'an (Qalyubi, 2008). Frase "stilistika al-Qur'an" lebih mengerucutkan objek kajian pada bahasa al-Qur'an. Dengan kata lain, stilistika al-Qur'an merupakan penggabungan antara objek formal dengan objek material penelitian. Dalam bahasa Arab, stilistika alQur'an disebut dengan uslüb al-Qur'an. Penyebutan ini merupakan bentuk id̄âfah (Malik, n.d.) yang menyimpan makna fi (di dalam) di antara kedua kata tersebut, sehingga dapat dikatakan bahwa uslūb alQur'an berarti gaya bahasa di dalam al-Qur'an.

Teori yang akan digunakan dalam tulisan ini, sebagaimana dikutip oleh Qalyubi dalam bukunya stilistika al-Qur'an, yaitu teori 
stilistika Fathullah Ahmad Sulaiman yang memfokuskan kajian pada aspek nash/tuturan. Teori tersebut mendasarkan pada asumsi bahwa karya sastra adalah satu kesatuan sehingga pemilihan kata, kalimat, dan wacana harus beralasan dan satu sama lain memiliki relasi yang kokoh (Qalyubi, 2008).

Menurut penulis, teori yang dikemukakan Fathullah berada pada sudut pandang pembuat stilistika (produsen gaya bahasa). Bagaimana seseorang bisa mempercantik bahasa, baik dalam bentuk ujaran maupun teks, dengan memilih kata atau memanipulasinya. Seseorang juga harus mengetahui lawan bicara, situasi berbicara dan konteks permasalahan, sehingga pesan yang terkandung dapat sampai dengan sempurna.

Pembacaan sebuah teks menggunakan stilistika, dengan demikian, mampu memunculkan gambaran komunikasi saat teks diutarakan. Ini menjadi modal untuk mencari makna yang lebih dalam. Menurut Husein Muhammad, teks (al-Qur'an) hadir di tengah-tengah kebudayaan masyarakat untuk berdialog, merespon kehidupan (Muhammad, 2016).

\section{b. Al-Mustawā Al-Ṣarfi (ranah morfologi)}

1) Iqra (إقرأ).

Iqra merupakan derivasi dari kata qaraa yang mempunyai arti membaca(Munawwir, 2002). Kata ini mempunyai kedekatan makna dengan kata talā (تلا), karena keduanya memiliki arti membaca(Munawwir, 2002). Dalam linguistik arab, kata qaraa dan talā masuk ke dalam fi'il (kata kerja) muta'addì. Fi'il muta'addī adalah kata kerja yang membutuhkan objek untuk membuat sebuah kalimat lengkap atau bermakna, sehingga kalimat tersebut bisa dipahami. Muta'addì berlawanan dengan lāzim. Jika muta'addì membutuhkan objek agar maknanya bisa dipahami, maka lāzim tidak membutuhkan objek, namun maknanya sudah bisa dipahami ('Ali, n.d.).

Sekilas, kedua kata qaraa dan talā memiliki arti sama, namun jika ditelusuri kedua kata ini memiliki penggunaan yang berbeda dalam sebuah kalimat. Perbedaan penggunaan terletak pada penempatannya dengan kata setelahnya sebagai maf'ūl bih (objek). 
Kata talā biasa disandingkan (meminjam bahasa Saussure yaitu disintagmatikkan) dengan objek bacaan berupa firman Allah. Menurut Mardjoko, kata talā digunakan dalam hal yang berhubungan dengan wahyu Allah kepada Rasulullah Muhammad (Idris, 2008), yang sifatnya suci (al-Qur'an) ataupun bacaan-bacaan suci lainnya yang tidak diturunkan kepada Rasulullah Muhammad.

Sebagaimana terdapat dalam surat al-Fātị: 29:

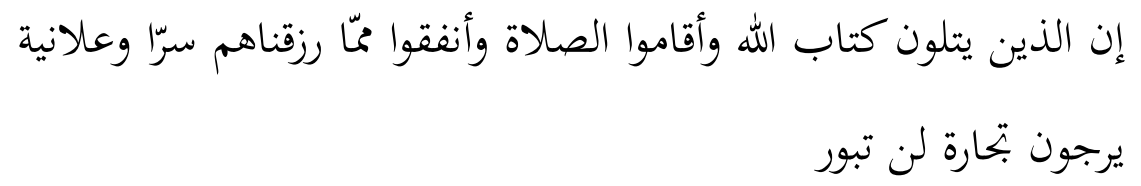

Artinya: "Sesungguhnya orang-orang yang selalu membaca kitab Allah dan mendirikan shalat dan menafkahkan sebagian dari rizki yang Kami anugerahkan kepada mereka dengan diam diam dan terang-terangan, mereka itu mengharapkan perniagaan yang tidak akan merugi".

Ayat di atas menggunakan kata yatlūna sebagai wakil dari arti membaca. Kata yatlūna yang digunakan pada ayat di atas bersandingan dengan frase kitāb Allāhi sebagai objeknya. Objek ini menunjuk pada kitab suci yang diturunkan oleh Allah. Dengan kata lain, objek yang dimaksud adalah segala kitab suci baik yang turun kepada Rasulullah Muhammad ataupun rasul-rasul yang lain, karena redaksi ayat menggunakan diksi kitäb bukan al-Qur'an. Berdasarkan penjelasan kata yatlūna dan frase kitāb Allahi tersebut, dapat dikatakan bahwa kata yatlūna memiliki objek berupa kitab suci yang diturunkan oleh Allah kepada rasul-rasulNya.

Berbeda dari kata talā yang memiliki objek khusus berupa kitab suci yang diturunkan oleh Allah, kata qaraa memiliki objek umum berupa segala bacaan yang bisa dibaca. Menurut Mardjoko kata qaraa dapat disandingkan (disintagmatikkan) dengan segala bacaan, baik bacaan yang bersifat umum maupun bacaan yang bersifat suci(Idris, 2008).

Bacaan yang bersifat suci terdapat dalam surat an-Nahl: 98:

$$
\text { فإذا قرأت القرآن فاستعذ بالله من الشيطان الرجيم }
$$


Artinya: “apabila kamu membaca al-qur'an hendaklah kamu meminta perlindungan kepada Allah dari setan yang terkutuk".

Ayat di atas menggunakan kata qaraa sebagai wakil dari arti membaca. Kata qaraa pada ayat di atas tidak lagi menunjukkan makna membaca segala bacaan, karena objek bacaan kata qaraa telah disebutkan, sehingga yang dimaksud dengan membaca pada ayat di atas adalah membaca al-Qur'an sebagai objek yang berada setelah kata qaraa.

Adapun kata qaraa yang terdapat pada wahyu pertama memiliki objek bacaan yang masih umum, karena objek bacaan tidak secara langsung disebutkan. Menurut penulis, efek yang ditimbulkan ketika membuang objek pada wahyu pertama adalah perasaan tenang terhadap orang orang Quraisy, karena awal revolusi peradaban yang dilancarkan Rasullah Muhammad bersifat persuasif. Selain itu, pembuangan objek qaraa juga memberikan efek mudah bagi manusia ketika mengingat Tuhan. Wahyu pertama memberikan kebebasan kepada manusia untuk mengingat Tuhan. Tidak hanya membaca kitab-kitab yang telah diturunkan, namun terhadap segala bacaan di luarnya baik tertulis maupun yang tidak tertulis.

2) Khalaqa (خلق).

Kata khalaqa mempunyai arti menjadikan, membuat, dan menciptakan (Munawwir, 2002). Kata khalaqa merupakan kata kerja yang membutuhkan objek (muta'addī), sehingga makna dapat dipahami. Ada dua kata khalaqa dalam wahyu pertama, yaitu khalaqa pada ayat pertama yang tidak memiliki objek dan khalaqa pada ayat kedua yang memiliki objek.

Dilihat dari formula tata bahasa Arab di atas, kata khalaqa pada ayat pertama bukan berarti cacat karena tidak memiliki objek, namun pada khalaqa ini boleh jadi Tuhan sengaja menghilangkan objek untuk memberitahukan keluasan ciptaanNya. Menurut bintu Syāti kata khalaqa pada ayat pertama menunjukkan makna umum, sehingga tidak dicantumkan objeknya. Makna umum ini pada ayat kedua dispesifikasikan kepada manusia, karena al-Qur'an diturunkan untuk petunjuk manusia. 
Penggunaan kata khalaqa ini secara implisit memberitahukan kepada orang-orang Quraisy bahwa mereka lebih mulia derajatnya dibanding berhala yang mereka sembah. Tuhan menciptakan orangorang Quraisy dari sesuatu yang belum ada, sedangkan berhala diciptakan mereka dari sesuatu yang sudah ada. Ibnu Arabi, sebagaimana dikutip Sugiono, menjelaskan bahwa kata bada'a (yang memiliki arti sama dengan khalaqa) mengindikasikan pengertian menciptakan sesuatu yang baru yang belum pernah ada contohnya dalam peringkat perwujudan. Sebab, Ia (Pencipta) mengetahui dan menguasai setiap yang ada dalam segala peringkat wujud sehingga manusia diciptakan tidak melalui sesuatu entitas yang sudah ada(Sugiono, 2013).

Sebagaimana firman Allah dalam surat al-Insān ayat 1:

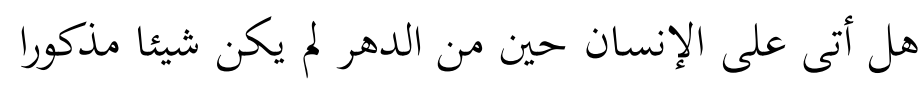

Artinya: "Bukankah telah datang atas manusia satu waktu dari masa, sedang dia ketika itu belum merupakan sesuatu yang dapat disebut?".

Selain itu, melalui penggunaan khalaqa juga Allah memberitahukan secara lembut bahwa Saya lebih kuasa daripada berhala karena dapat menciptakan segala sesuatu, sehingga Saya tidak memiliki tandingan. Menurut Imam ar-Rāzì, sebagaimana dikutip bintu Syāti, kata khalaqa dipilih untuk menggantikan klausa lā syarika lahu yang bertujuan untuk mengenalkan Tuhan kepada para penyembah berhala. Sebab, apabila klausa tersebut langsung disebutkan, maka mereka secara langsung enggan menerima risalah yang dibawa Rasulullah Muhammad (Asy-Syati, n.d.).

Berbeda dari khalaqa dan bada'a, ja'ala yang juga memiliki arti menjadikan atau menciptakan menunjukkan makna penciptaan sesuatu dari materi yang sudah ada. Al-Așfahāni menjelaskan bahwa ada lima sifat yang melekat pada kata ja'ala, satu diantaranya yaitu menjadikan sesuatu dari sesuatu yang lain, sehingga keberadaannya ditentukan dari sesuatu yang lain tersebut (Al-Ashfahani, n.d.). Menurut bahasa Sugiono keberadaan sesuatu disebabkan melalui 
proses reproduksi dengan cara mengubah kedudukan atau fungsi (Sugiono, 2013), sebagaimana firman Allah dalam surat an-nahl: 30:

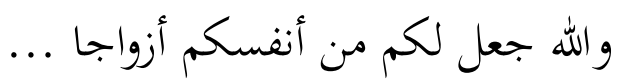

Artinya: "Allah menjadikan bagi kamu istri-istri dari jenis kamu sendiri ...".

Dalam ayat ini, Allah menggunakan kata ja'ala untuk menciptakan pasangan, karena pada ayat lain dijelaskan bahwa pasangan seseorang sesuai dengan tulang rusuknya. Artinya, pasangan diciptakan melalui suatu bahan yaitu tulang rusuk. Penjelasan yang umum diketahui yaitu Tuhan menciptakan Hawa melalui tulang rusuk nabi Adam.

3) 'Allama (علّم) dan ya'lamu (يعلم).

Kata 'allama merupakan derivasi dari kata 'alima yang berarti mengerti, mengetahui. Kemudian ditambahkan tasydid pada huruf lam menjadi 'allama yang berarti mengajar, mendidik (Munawwir, 2002). Adapun kata ya'lamu merupakan bentuk mud̄ori' dari kata 'alima yang mengikuti wazan fa'ila, yaf'alu ('Ali, n.d.). Dari sini dapat diketahui bahwa kedua kata tersebut mempunyai akar kata yang sama yaitu 'alima.

Kata 'alima merupakan kata kerja yang membutuhkan objek. Menurut al-Așfahāni kata 'alima memiliki dua perbedaan jumlah objek, yaitu: kata 'alima yang memiliki satu objek dan kata 'alima yang memiliki dua objek. Perbedaan jumlah objek mempengaruhi makna dalam sebuah kalimat. Kata 'alima yang memiliki satu objek bermakna mengetahui suatu entitas menggunakan entitas itu sendiri, sedangkan kata 'alima yang memiliki dua objek bermakna mengetahui suatu entitas menggunakan entitas yang lain (maujūdun lahu) (Al-Ashfahani, n.d.).

Ada tiga kata 'alima yang terdapat dalam wahyu pertama. Dua mengikuti wazan fa'ala dan satu berupa fi'il muḍāri'. Kata 'alima pada ayat keempat tidak memiliki objek. Peniadaan objek pada ayat keempat bukan berarti menyalahi aturan tata bahasa Arab. Peniadaan objek tersebut bisa saja memiliki maksud lain, yaitu mengajarkan apa 
saja kepada siapa saja. Dengan kata lain, Allah menghendaki objek sasaran yang tak terbatas untuk membuktikan ke-Maha KuasaanNya. Keluasan maksud pada ayat keempat, selanjutnya dipersempit kepada ranah manusia, karena al-Qur'an diturunkan kepada manusia, sehingga pada ayat kelima dimunculkan satu objek berupa manusia.

Kemunculan satu objek ini bukan tanpa alasan. Menurut penulis, kemunculan satu objek memberikan efek datar untuk meminimalisir kecurigaan doktrin tersembunyi yang dibawa Rasulullah Muhammad, karena kata 'alima yang memiliki satu objek bermakna mengetahui suatu entitas menggunakan entitas itu sendiri. Ini merupakan sebuah tahapan awal untuk mengetahui suatu entitas menggunakan entitas lain. Dalam konteks agama dapat diartikan dengan mengetahui Allah menggunakan ciptaanNya. Apabila arti yang kedua ini digunakan dalam wahyu pertama, maka besar kemungkinan akan terjadi penolakan yang lebih keras.

Alasan selanjutnya melalui perspektif berbeda, yaitu Allah tidak perlu mengetahui sesuatu menggunakan sesuatu yang lain, karena Allah memiliki sifat Maha Tahu. Allah mengetahui sesuatu melalui sesuatu itu sendiri. Seandainya Allah menggunakan sesuatu yang lain untuk mengetahui sesuatu maka Allah memerlukan bantuan makhlukNya, sehingga memiliki sifat lemah dan hal ini tidak akan mungkin terjadi.

Berdasarkan kedekatan makna dengan kata-kata yang lain, kata 'alima memiliki ciri khas pemaknaan sendiri, yaitu mengetahui sesuatu secara rinci baik referensial maupun non referensial. Menurut Mardjoko kata 'alima berarti mengetahui sesuatu baik yang tampak maupun tidak secara detail menggunakan indera. Prosesnya harus dilakukan berulang-ulang agar bisa menempel dengan kuat, sehingga tercipta keyakinan (Astari \& Idris, 2009).

Arti kata 'alima di atas sangat tepat digunakan pada ayat kelima terakhir wahyu pertama (mā lam ya'lam). Dalam konteks awal mula dakwah Rasul, penggunaan kata ini memberitahukan bahwa keyakinan yang diterima secara turun-temurun dari nenek moyang orang-orang Quraisy melalui indera dan dilaksanakan secara terus 
menerus merupakan keyakinan yang salah. Hal ini dapat dilihat melalui redaksi ayat yang memasukkan morfem negatif berupa lam.

Melalui makna 'mengetahui sesuatu yang dalam karena proses pencarian pengetahuan dilakukan secara berulang' ini muncul kata yang disematkan kepada orang-orang pandai dalam hal agama, yaitu 'ālim dan 'ulamā. Posibilitas penggunaan kata 'ālim adalah mereka yang pandai dalam ilmu agama membutuhkan waktu lama untuk mendapatkan pengetahuan yang mendalam. Disamping itu, mereka juga membutuhkan proses yang dilakukan secara berulang-ulang untuk memantapkan keyakinan pengetahuannya. Berbeda dengan para wali yang tidak butuh waktu lama untuk mengetahui sesuatu secara detail.

Untuk memperkuat arti kata 'alima di atas, berikut akan dijelaskan kata-kata yang memiliki kedekatan makna dengannya, sehingga didapatkan perbedaan yang signifikan. Pertama, kata 'arafa. Kata 'arafa menurut al-Aṣfahāni lebih khusus dibanding dengan kata 'alima. Kata 'arafa merupakan kata 'alima yang memiliki objek dua. Sebagaimana dijelaskan di atas bahwa kata 'alima yang memiliki dua objek bermakna mengetahui sesuatu dengan sesuatu yang lain, sehingga untuk mengetahui Tuhan maka manusia menggunakan kata 'arafa, seperti: fulānun ya'rifu Allāha (Al-Ashfahani, n.d.).

Selain digunakan untuk kata 'alima yang memiliki dua objek, kata 'arafa juga digunakan untuk mengetahui sesuatu secara dangkal. Dalam konteks pemaknaan ini, kata 'arafa memiliki kualitas lebih rendah dibanding kata 'alima. Menurut Mardjoko, kata 'arafa bermakna mengetahui suatu hal, baik referensial maupun non referensial, dengan menggunakan indera untuk mendapatkan bukti yang sedikit, sehingga berdampak pada pengetahuan yang dangkal, sekedarnya, dan tidak mendalam. Meskipun kata 'arafa memiliki bukti yang sedikit dan pemahaman yang dangkal, namun kata 'arafa tetap mempercayai pengetahuan yang diterimanya(Astari \& Idris, 2009).

Sebagaimana terdapat dalam surat al-An'ām: 20: 


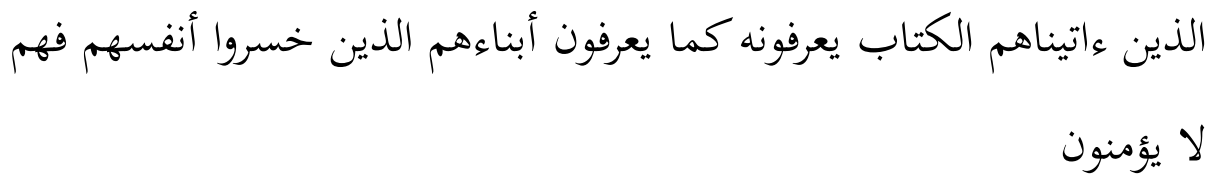

Artinya: “Orang-orang yang telah kami berikan kitab kepadanya, mereka mengenalnya (Muhammad) seperti mereka mengenal anak-anaknya sendiri. Orang-orang yang merugikan dirinya, mereka itu tidak beriman".

Ayat di atas menggunakan kata 'arafa yang menunjukkan bahwa orang-orang Yahudi dan Nasrani mengenal Muhammad melalui kitab-kitab mereka. Imam ar-Rāzī menjelaskan bahwa di dalam taurat dan injil terdapat keterangan yang mengatakan bahwa di akhir zaman akan datang seorang nabi yang mengajak manusia kepada agama yang benar(Al-Razi, 2009). Pengetahuan tersebut diperkuat melalui indera tentang tanda-tanda kenabian dan kerasulannya, meskipun tidak mendalam.

Kedua, kata adraka. Kata adraka, dalam kamus al-Munawwir, bermakna mengerti, memahami. Kata adraka termasuk dalam kategori fi'il muta'addì. Sebagai fi'il muta'addì, adraka juga memiliki objek sebagaimana 'alima dan 'arafa. Perbedaannya terletak pada wujud objek tersebut. Kata 'alima dan 'arafa memiliki objek yang tampak maupun yang tidak tampak, sedangkan kata adraka memiliki objek yang tampak. Jadi, berdasarkan keberadaan objek, kata adraka lebih khusus dibanding dengan kata 'alima dan 'arafa.

Penjelasan di atas, senada dengan pendapat yang diutarakan Mardjoko. Menurutnya kata adraka bermakna mengetahui suatu hal yang sudah memiliki bentuk menggunakan indera, sehingga dapat mempengaruhi pola pikir dan tingkah laku. Disamping itu, kata adraka juga digunakan untuk menghasilkan teori melalui pemikiran dan perenungan objek, sehingga dapat menyangkal pengingkaran (Astari \& Idris, 2009).

Sebagaimana yang terdapat dalam surat al-Anām: 103:

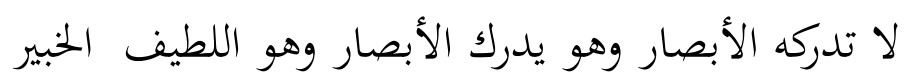


Artinya: "Dia tidak dapat dicapai oleh penglihatan mata, sedang Dia dapat melihat segala yang kelihatan, dan Dialah yang Maha Halus lagi Maha Mengetahui".

Ayat di atas menggunakan kata adraka yang menunjukkan bahwa manusia tidak mampu melihat sesuatu di luar batas kemampuan. Manusia hanya bisa melihat sesuatu yang konkret (nyata). Adapun pemakaian kata adraka pada Allah, menurut sebagian ahli bahasa, sebagaimana dikutip Mardjoko adalah untuk arti menjangkau dan menguasai(Astari \& Idris, 2009).

4) Rabbun (رّ)

Rabbun adalah salah satu dari sembilan puluh sembilan nama Allah yang biasa dikenal dengan asma al-husna. Kata Rabbun berasal dari fi'il māộ̀ Rabba yang berarti memimpin, memelihara, mengasuh, dan mendidik (Munawwir, 2002). Kata Rabbun adalah bentuk mașdar isti'ärah (masdar pinjaman), karena orang Arab meminjam tata bahasanya untuk disematkan kepada nama Allah.

Pendapat senada diutarakan Al-Aṣfahāni yang menjelaskan bahwa kata Rabbun tidak boleh dipakai kecuali untuk Allah. Lebih lanjut dijelaskan bahwa kata Rabbun tidak boleh digunakan dalam bentuk jama', yaitu arbābun, karena penggunaan jama' menyalahi doktrin agama tentang ke-Esaan Tuhan. Oleh karena itu, dalam menafsirkan Q.S. Yūsuf: 39 yang berbunyi “aarbābun mutafarriqūna khairun am Allāhu al-Wāhid al-Qahhār", al-Aṣfahāni memberikan argumen bahwa bentuk jama' arbäbun digunakan untuk menghitung jumlah keyakinan orang-orang kafir, bukan digunakan untuk sesuatu Dzat (Al-Ashfahani, n.d.).

Berdasarkan argumen yang dijelaskan al-Așfahāni di atas, penggunaan bentuk mufrad pada kata Rabbun dalam ayat pertama wahyu pertama sangat tepat. Penggunaan bentuk mufrad merupakan ajaran tauhid pertama yang dikemas secara persuasif, laten, dan hatihati. Penggunaan bentuk mufrad merupakan sebuah antitesa kepercayaan masyarakat Quraisy. Penggunaan bentuk mufrad dapat mempengaruhi dan menggoyahkan keyakinan orang-orang Quraisy yang mempercayai adanya banyak tuhan. 
Dilihat dari sisi pilihan kata, kata Rabbun merupakan kata yang tepat digunakan dalam wahyu pertama. Tercatat ada dua kata Rabbun dalam wahyu pertama, yaitu: iqra bismi rabbika al-lażī khalaq pada ayat pertama dan iqra wa rabbuka al-akram pada ayat ketiga. Keduanya memiliki korelasi sintagmatik dengan kata sebelumnya, yaitu iqra. Menurut imam Zamakhsyarī kedua kata ini memiliki hubungan action (tindakan), yaitu aktivitas membaca dilakukan setelah menyebut nama Allah terlebih dahulu. Dalam hal ini, Zamakhsyarī tidak menspesifikasikan bacaan pada al-Qur'an, sehingga aktivitas membaca bersifat umum (Al-Zamakhsyari, 1998).

Berbeda dari imam Zamakhsyarī yang memberikan sifat umum pada aktivitas membaca, imam ar-Rāzī, sebagaimana dikutip bintu asy-Syāti, memberikan spesifikasi aktivitas membaca pada al-Qur'an. Menurutnya, nama Allah harus disebutkan terlebih dahulu sebelum membaca al-Qur'an(Asy-Syati, n.d.).

Masih berhubungan dengan action bahwa nama Rabbun lebih dipilih daripada nama Allah dalam wahyu pertama. Menurut imam ar-Rāzì, penggantian nama ini dilakukan karena Allah merupakan nama yang bersandar pada DzatNya, sedangkan Rabbun merupakan nama yang bersandar pada aktivitas Tuhan. Oleh karenanya, dalam menjalankan ibadah diharuskan menggunakan nama Tuhan berdasarkan PekerjaanNya, bukan menggunakan nama Tuhan berdasarkan Dzatnya (Al-Razi, 2009).

Akan tetapi, menurut penulis, pendapat imam ar-Rāzì dapat mempersulit orang muslim awam, karena merasa bingung dalam mencari Nama Tuhan yang bersandar pada AktivitasNya ketika orang muslim hendak melakukan sesuatu. Selain itu, pencarian Nama ini juga membutuhkan waktu lama bagi mereka, sehingga nama Allah berupa frase bismillähi dapat digunakan sebagai pengganti untuk mempermudah orang muslim melakukan sesuatu. Menurut Mahmud, frase bismilläh dapat mencakup segala namaNya (Mahmud, 1997). Boleh jadi, ini merupakan salah satu alasan tidak adanya kata kerja sebelum bismillāhirrahmānirrahìm.

Selain berhubungan dengan kata sebelumnya, ketepatan kata Rabbun juga berhubungan dengan kondisi Rasulullah Muhammad 
saat menerima wahyu. Pada saat malaikat Jibril membacakan kata iqra, Rasulullah Muhammad mengalami rasa takut. Ketakutan Rasulullah bertambah saat Jibril mengulang kata iqra tiga kali. Dalam kondisi ini muncul kata Rabbun yang berguna untuk meredakan rasa takut Rasulullah. Bintu asy-Syāti menjelaskan kata Rabbun berfungsi untuk mengingatkan Rasulullah dari rasa takut. Lebih lanjut bintu asy-Syāti menjelaskan kata Rabbun menggunakan dua penafsiran, pertama, peringatan untuk tidak berbuat malas, karena Allah telah mendidik dan memberikan takdir, kedua, tidak boleh menyianyiakan sesuatu setelah menjadi manusia, karena Allah telah mendidik sejak 'alaqah (Asy-Syati, n.d.).

\section{Kesimpulan}

Kata iqra merupakan bentuk kata kerja yang membutuhkan objek. Namun, pada wahyu pertama tidak didapatkan objek setelah kata tersebut. Hal ini bukan berarti wahyu pertama cacat di hadapan tata bahasa Arab. Pembuangan objek lebih dimaksudkan kepada strategi dakwah secara persuasif tanpa menyebutkan kitab suci yang dibawa Rasulullah. Penghilangan objek juga terjadi pada kata khalaqa ayat pertama. Kemunculan objek khalaqa pada ayat kedua mengindikasikan adanya sentakan makna setelah disembunyikan terlebih dahulu. Tuhan ingin memberitahukan bahwa orang-orang Quraisy lebih mulia dibanding dengan sesembahan mereka. Sebab kata khalaqa bermakna penciptaan melalui bahan-bahan yang belum ada. Kata 'alima memiliki arti mengetahui sesuatu secara rinci baik referensial maupun non referensial. Prosesnya harus dilakukan secara berulang-ulang agar pengetahuan menancap kuat sehingga tercipta keyakinan. Pada ayat kelima, frase mā lam ya'lam secara implisit memberitahukan kepada orang-orang Quraisy bahwa keyakinan yang selama ini tercitra melalui pemujaan merupakan keyakinan yang keliru yang diwariskan oleh nenek moyang. Kata Rabbun merupakan ajaran tauhid pertama yang dikemas secara persuasif, laten, dan hatihati. Penggunaan bentuk mufrad merupakan sebuah antitesa kepercayaan masyarakat Quraisy. Kata Rabbun juga memiliki hubungan erat dengan kata sebelumnya, yaitu iqra. Proses mencari 
pengetahuan harus selalu mengingat Tuhan sebagai Rabb (Pendidik) agar pengetahuan bisa didapatkan secara benar.

\section{Referensi}

'Ali, M. M. bin. (n.d.). Al-Amtsilah Al-Tashrifiyyah. Semarang: Wicaksana.

Al-Ashfahani, A.-R. (n.d.). Mufradat Al-Fadz Al-Qur'an.

Al-Jahiz, A. U. A. bin B. (1948). Al-Bayan wa Al-Tabyin. Dar Al-Fikr.

Al-Razi, F. (2009). Al-Tafsir Al-Kabir. Lebanon: Dar Al-Kotob AlIlmiyah.

Al-Zamakhsyari, A. A.-Q. M. bin U. (1998). Al-Kasyaf. Riyad: Maktabah al-'Abikan.

Astari, R., \& Idris, M. (2009). Semantik Al-Qur'an: Tinjauan Makna Kosakata. Yogyakarta: Mitra Cendekia.

Asy-Syati, 'Aisyah Abdurrahman Bintu. (n.d.). At-Tafsir Al-Bayani li Al-Qur'an Al-Karim. Mesir: Dar Al-Ma'arif.

Pusat Bahasa Depdiknas. (1988). Kamus Besar Bahasa Indonesia. Jakarta: Balai Pustaka.

Finkel, I. (2014). Bahtera Sebelum Nabi Nuh. Tangerang: Alvabet.

Idris, M. (2008). Semantik Al-Qur'an: Pertentangan dan Perbedaan Makna. Sleman: Teras.

Khitam, A. K. (2017). At-Tanāwub, At-Taqdīm Wa At-Ta'khīr, Dan AlIltifāt( Kajian Stilistika al-Qur'an dan Puisi Arab). Mukadimah: Jurnal Studi Islam. 2(1), 1-18.

Kridalaksana, H. (2009). Kamus Linguistik. Jakarta: Gramedia.

Mahmud, A. H. (1997). Bacalah dengan Nama Tuhanmu: Mengungkap Kandungan Ayat Pertama Al-Qur'an. Jakarta: Lentera.

Malik, J. M. bin A. bin. (n.d.). Syarah Ibnu 'Aqil 'Ala Al-Fiyyah. Daru Ihya Al-Kutub Al-'Arabiyyah.

Muhammad, H. (2016). Memahami Maksud dan Cita-Cita Tuhan. Nun Jurnal Studi Alqur'an Dan Tafsir Di Nusantara, 2, 1-26.

Munawwir, A. W. (2002). Al-Munawwir: Kamus Arab-Indonesia. Surabaya: Pustaka Progresif.

Qalyubi, S. (2008). Stilistika dalam Orientasi Studi Al-Qur'an. Sleman: Belukar. 
Muhammad Alghiffary

Ratna, N. K. (2009). Stilistika: Kajian Puitika Bahasa, Sastra, dan Budaya. Yogyakarta: Pustaka Pelajar.

Ratna, N. K. (2010). Metodologi Penelitian: Kajian Budaya dan Ilmu Sosial Humaniora pada Umumnya. Yogyakarta: Pustaka Pelajar.

Sugiono, S. (2013). Manusia dan Bahasa: Upaya Meretas Semantik Kun Fayakun. Yogyakarta: IDEA Press. 